\title{
Effect of Sources and Levels of Sulphur on Growth, Yield and Quality of Onion (Allium cepa L.)
}

\author{
M.A. Chattoo, M. Mudasir Magray*, Ajaz Ah Malik, M.D. Shah and J.A. Chisti \\ Division of Vegetable Science, Skuast, Kashmir-190025, India \\ *Corresponding author
}

\section{A B S T R A C T}

\section{Keywords \\ Onion, Sulphur, Sources, Levels, Growth, Yield, Quality and storage \\ Article Info \\ Accepted: \\ 12 January 2019 \\ Available Online: \\ 10 February 2019}

An experiment was conducted during rabi-2010-11, 2011-2012 and 2012-2013 at Faculty of Agriculture and Regional Research Station, wadura Sopore, SKUASTKashmir. The treatment consists two sources of sulphur (Gypsum and elemental sulphur) and four levels of sulphur $\left(0,15,30,45 \mathrm{~kg} \mathrm{ha}^{-1}\right)$. The experiment was laid in a randomised block design with three replications. It was observed that application of sulphur as gypsum recorded maximum growth, yield and quality parameters besides enhancing quality and storage life of bulbs as compared to elemental sulphur. Further it was proved that application of sulphur @ $45 \mathrm{~kg} \mathrm{ha}^{-1}$ resulted in significant improvement in most of growth, yield and quality parameters besides enhancing nutrient uptake by crop as well as improving storage life of onion bulbs.

\section{Introduction}

Onion (Allium cepa L.) "queen of kitchen" is one of the most important commercial crop not only in India but also in the world. India ranks first in area, and next in production after china. In India, onion is being grown in an area of 1270.00 (000 ha) with a production of $21564.00(000 \mathrm{t})$ and the productivity is 17.30 $\mathrm{t} \mathrm{ha}^{-1}$ (Annoymous, 2017). Although India has highest area under onion, still it stands second in the production of onion in the world. Hence there is a lot of potential for increasing the production by improving the yields.

In Kashmir onion is grown on an area of 950 ha with a annual production of $24250 \mathrm{t}$ and the productivity is $25.52 \mathrm{t} \mathrm{ha}^{-1}$ (Annoymous, 2017). Since the India is the larger exporter of onion foreign exchange. Productivity could be increased by use of suitable varieties, balanced nutrition, need based agronomic practices. Among the many constraints for low production in onion, imbalanced nutrition is the main limiting factor. Sulphur has been recognised fourth major plant nutrient after nitrogen, phosphorus and potassium in crops. Sulphur deficiency is increasing in Indian soils at a faster rate and this has adversely affect the crop production even though crop is applied with recommended dose of N,P,K fertilisers Onion is a sulphur loving plant and the requirement is high for its proper growth and yield. Sulphur is recognised as an 
important nutrient for higher yield and better quality of onion bulbs (Thippeswamy, 1993, Tripathy et al., 2013). Severe sulphur deficiency during bulb development has detrimental effect on an alkaloid allylpropyl disulphide, in which sulphur is the prime constituent. Sulphur application not only improves the bulb yield, pungency, flavours. Other quality parameters but also improves shelf life also, besides imparting resistance against pests and diseases, Jaggi and Dixit,1999 and Magray et al., 2017. Sulphur is essential for building up of sulphur containing amino acids, which are building blocks for essential proteins in plants. It is essential for vegetative growth and bulb development in onion (Anwar et al., 2001). Sulphur deficiency in Indian soils becomes more prevalent due to extensive use of sulphur free fertilisers. No sulphur application in sulphur deficient soils has often resulted in low yield of onion. Keeping in view the significance of sulphur in the production of onion crop, the present investigation "Effect of Different Sources and Levels of sulphur on growth, yield and quality of onion cv. yellow onion was undertaken.

\section{Materials and Methods}

A field experiment was conducted during rabi-2010-11,2011-2012 and 2012-2013 at Faculty of Agriculture and Regional Research Station, wadura Sopore, SKUAST-Kashmir. Soil of the experimental plot was clay cloam, having PH of 7.21, Soil organic Carbon $0.60 \%$, Electrical conductivity $0.160 \mathrm{dsm}^{-1}$, available $\mathrm{N}, \mathrm{P}, \mathrm{K}$ and $\mathrm{S}, \quad 315$, 18.09:156.30:19.49 $\mathrm{kg} \mathrm{ha}^{-1}$ respectively. The treatment consists two sources of sulphur (Gypsum and elemental sulphur) and four levels of sulphur $\left(0,15,30,45 \mathrm{~kg} \mathrm{ha}^{-1}\right)$. The experiment was laid in a randomised block design with three replications. The gypsum as a source of sulphur as per treatments as per treatments was applied at the time of transplanting, while elemental sulphur was applied before 15-20 days of transplanting. The recommended dose of phosphorus $(50 \mathrm{~kg}$ $\left.\mathrm{ha}^{-1}\right)$, potash $\left(80 \mathrm{~kg} \mathrm{ha}^{-1}\right)$, half dose of nitrogen $\left(75 \mathrm{~kg} \mathrm{ha}^{-1}\right)$ were applied as top dose on the onset of March. Farmyard manure of seven weeks old were tranplanted @20 t ha ${ }^{-1}$ at a spacing of $15 \times 10 \mathrm{cms}$ in plots of $6.0 \times$ $2.00 \mathrm{~m}$ size in the last week of November during 2010-13.Recommended package of practices was adopted to raise a healthy crop. The crop was harvested in last week of June in all the three years. The Observations on growth, yield, quality, storage life, nutrient uptake and availability were recorded, using standard procedures. The recorded data was subjected to stastiscal analysis as per the procedure suggested by Panse and Sukhatame (1978).

\section{Results and Discussion}

Effect on growth and yield attributing parameters are presented in table 1

\section{Effect of sources of sulphur}

\section{Growth and yield parameters (Table 2)}

The results on vegetative parameters as influenced by sources indicate a varied response. Number of leaves and plant height showed significant variations, gypsum recording maximum values of $72.57 \mathrm{~cm}$ and 12.11 for plant height and number of leaves plant $^{-1}$ respectively as compared to elemental sulphur $\left(69.25 \mathrm{~cm}, 10.72\right.$ leaves plant $\left.{ }^{-1}\right)$. Neck thickness and collar thickness exhibited a non-significant response to sulphur sources recording lower values of 10.22 and $1.80 \mathrm{~cm}$ respectively with gypsum.

As per table 2 Yield and yield related attributes were significantly influenced by sulphur sources, gypsum proved superior to elemental sulphur. Gypsum recorded higher 
values of $6.52 \mathrm{~cm}, 6.13 \mathrm{~cm}$ and 86.26 gram, $436.41 \mathrm{q} \mathrm{ha}^{-1}$ and $405.73 \mathrm{q} \mathrm{ha}^{-1}$ for equatorial diameter, polar diameter, average bulb weight, total bulb yield and marketable yield respectively and were significantly superior to the values recorded with elemental sulphur. Gypsum as a source of sulphur gave an additional bulb yield of $17.54 \mathrm{q} \mathrm{ha}^{-1}$ over elemental sulphur.

\section{Quality parameters}

Keeping quality, TSS and Pyruvicid acid content of onion bulbs was significantly influenced by sulphur sources, gypsum recorded a storage loss of 30.96 which was $3.19 \%$ less, than that recorded with elemental sulphur (34.15) (Table 3).

Gypsum recorded significantly higher values of $11.01 \%$ and $6.75 \mu^{-10 l g}{ }^{-1}$ for TSS and pyruvic acid respectively as compared to elemental sulphur $\left(10.51 \%\right.$ and $\left.6.54 \mu \mathrm{molg}^{-1}\right)$.

\section{Nutrient uptake}

Nutrient uptake depicted a significant response to sulphur applications. Gypsum recorded a uptake of $85.25,20.51,70.82$ and $27.93 \mathrm{~kg} \mathrm{ha}{ }^{-1}$ for nitrogen, phosphorus, potassium and sulphur respectively and were found significantly superior to the values recorded with elemental sulphur.

Nutrient build up after harvest, resulted an improvement, nitrogen and potassium depicted a non significant build up, while in phosphorus and sulphur, the build up was significant.

Gypsum proved superior to elemental sulphur, recording a nutrient build up of $380.74,29.20,205.22$ and $27.38 \mathrm{~kg} \mathrm{ha}^{-1}$ for nitrogen, phosphorus, potassium and sulphur respectively (Table 2 ).

\section{Effect of levels of sulphur}

\section{Growth and yield parameters}

The data on growth, yield and yield attributes depicted influenced by different levels of sulphur indicate significant variations among different levels of sulphur. A marked increase in the values was observed with the increasing levels.

Application of sulphur@45 $\mathrm{kg} \quad \mathrm{ha}^{-1}\left(\mathrm{~L}_{4}\right)$ recorded significantly highest values of 76.40 $\mathrm{cm}$ for plant height as compared to all levels. $\mathrm{L}_{4}\left(45 \mathrm{~S} \mathrm{~kg} \mathrm{ha}^{-1}\right)$ recorded a leaf number of $12.88 \mathrm{~cm}$, which was significantly superior to $\mathrm{L}_{1}$ (10.09) and $\mathrm{L}_{2}$ (10.82) but was statistically at par with $\mathrm{T}_{3}$ (11.86). Neck Thickness and collar thickness recorded lower values of 0.18 $\mathrm{cm}$ and $1.54 \mathrm{~cm}$, which were significantly lower to the values recorded with other levels, but exhibited at par results with $\mathrm{T}_{3}(30 \mathrm{~kg} \mathrm{~S}$ $\mathrm{ha}^{-1}$ ) with respect to collar thickness (1.74 $\mathrm{cm})$. Significant variations among sulphur levels were observed with respect to yield and yield related attributes of onion (Table 2).

Sulphur level $\mathrm{L}_{4}\left(45 \mathrm{~kg} \mathrm{ha}^{-1}\right)$ significantly registered higher values of $6.84 \mathrm{~cm}, 6.55 \mathrm{~cm}$, 93.43g, 452.51 q ha ${ }^{-1}$ and $483.03 \mathrm{q} \mathrm{ha}^{-1}$ for equatorial diameter, polar diameter, average bulb weight, total bulb yield and marketable yield respectively as compared to other levels. Sulphur level $45 \mathrm{~kg} \mathrm{ha}^{-1}\left(\mathrm{~L}_{4}\right)$ registered an increase in yield by $29.32 \%, 16.25 \%$ and $10.14 \%$ over $\mathrm{L}_{1}\left(0 \mathrm{~kg} \mathrm{Sha}^{-1}\right), \mathrm{L}_{2}\left(15 \mathrm{~kg} \mathrm{ha}^{-1}\right)$ and $\mathrm{L}_{3}\left(30 \mathrm{~kg} \mathrm{ha}^{-1}\right)$ respectively. Similar findings have also been reported by Kumar and Singh (1994), Channagourda et al., (2009) in onion and Magray et al., (2017) in garlic.

\section{Quality parameters (Table 3)}

Significantly highest values of $11.54 \%, 7.06$ $\mu \mathrm{mol} \mathrm{g}{ }^{-1}$ were recorded with the application 
of $45 \mathrm{~kg} \mathrm{~S} \mathrm{ha}^{-1}$ for TSS and pyruvic acid content. $\mathrm{L}_{4}\left(45 \mathrm{~kg} \mathrm{~S} \mathrm{ha}^{-1}\right)$ recorded a storage loss of $26.18 \%$ which was $13.78 \%$ less than that recorded with control (39.96\%) (Table 3).

\section{Nutrient uptake}

Significant variations were observed for nutrient uptake among sulphur levels. Sulphur application $\mathrm{L}_{4}\left(45 \mathrm{~kg} \mathrm{ha}^{-1}\right)$ recorded an uptake of $94.44,23.89,78.65$ and $32.54 \mathrm{~kg} \mathrm{ha}^{-1}$ for nitrogen, phosphorus, potassium and sulphur were found significantly superior the values recorded with rest of the levels.
Nutrient build up after harvest resulted an improvement in nitrogen availability depicted a non-significant build up, while phosphorus, potassium and sulphur resulted in a significant build up. $\mathrm{L}_{4}\left(45 \mathrm{~kg} \mathrm{ha}^{-1}\right)$ recorded higher nutrient build up of $386.23,30.43$, 189.34 and $30.04 \mathrm{~kg} \mathrm{ha}^{-1}$ for nitrogen, phosphorus, potassium and sulphur respectively (Table 4).

All the interaction effects on growth, yield and quality parameters were found nonsignificant except PWL \%.

Table.1 Initial status of experimental field with respect to available N, P, K, S, OC and soil pH

\begin{tabular}{|c|c|c|}
\hline Character & Value & Method \\
\hline Organic carbon (\%) & 0.60 & $\begin{array}{l}\text { Walkley and Blacks Method (1934) (Jackson, } \\
\text { 1973) }\end{array}$ \\
\hline Soil pH & 7.21 & $\begin{array}{l}\text { 1:2.5 soil water suspension with Beckman's Glass } \\
\text { Electrode pH Meter (Jackson,1967) }\end{array}$ \\
\hline Available N $\left(\mathrm{kg} \mathrm{ha}^{-1}\right)$ & 315 & $\begin{array}{l}\text { Subbiah and Asija (1956) } \\
\text { (Alkaline potassium permanganate method) }\end{array}$ \\
\hline Available $P\left(\mathrm{~kg} \mathrm{ha}^{-1}\right)$ & 18.09 & $\begin{array}{l}\text { Olsens Method (1954) } \\
\text { (Extraction with } 0.5 \mathrm{M} \mathrm{NaHCO}_{3} \text { ) }\end{array}$ \\
\hline Available K $\left(\mathrm{kg} \mathrm{ha}^{-1}\right)$ & 156.30 & $\begin{array}{l}\text { Extraction with Neutral Normal Ammonium } \\
\text { Acetate (Jackson, 1967) }\end{array}$ \\
\hline Available $S\left(\mathrm{~kg} \mathrm{ha}^{-1}\right)$ & 19.49 & $\begin{array}{l}\text { Extraction by (Williamns and Steinberg, 1959) } \\
\text { method and determination by turbidimetric } \\
\text { (Chesnin and Yien, 1951) method }\end{array}$ \\
\hline
\end{tabular}


Table.2 Effect of various levels of sulphur on growth and yield contributing characteristics of onion (Allium cepa L.)

\begin{tabular}{|c|c|c|c|c|c|c|c|c|c|}
\hline Treatment & $\begin{array}{c}\text { Plant } \\
\text { height } \\
\text { (cms) }\end{array}$ & $\begin{array}{l}\text { No. of } \\
\text { leaves }\end{array}$ & $\begin{array}{l}\text { Equator } \\
\text { Dia } \\
(\mathrm{cms})\end{array}$ & $\begin{array}{c}\text { Polar } \\
\text { Dia } \\
(\mathrm{cms})\end{array}$ & $\begin{array}{c}\text { Neck } \\
\text { thickness } \\
(\mathrm{cms})\end{array}$ & $\begin{array}{c}\text { Collar } \\
\text { Thickness } \\
\text { (cm) }\end{array}$ & $\begin{array}{c}\text { Average bulb } \\
\text { weight (g) }\end{array}$ & $\begin{array}{c}\text { Marketable } \\
\text { Yield } \\
\text { q ha }\end{array}$ & $\begin{array}{c}\text { Total Bulb } \\
\text { Yield } \\
\text { qha }^{-1}\end{array}$ \\
\hline \multicolumn{10}{|l|}{ Sources } \\
\hline $\mathbf{S}_{1}$ & 72.57 & 12.11 & 6.52 & 6.13 & 0.22 & 1.80 & 86.26 & 405.73 & 436.41 \\
\hline $\mathbf{S}_{2}$ & 69.33 & 10.72 & 6.23 & 5.80 & 0.23 & 1.86 & 80.98 & 372.09 & 418.87 \\
\hline C.D & 1.75 & 0.76 & 0.16 & 0.16 & NS & NS & 2.06 & 9.51 & 11.23 \\
\hline \multicolumn{10}{|l|}{ Levels } \\
\hline $\mathrm{L}_{1}=0 \mathrm{~kg} \mathrm{ha}^{-1}$ & 63.94 & 10.09 & 5.83 & 5.36 & 0.28 & 2.15 & 74.49 & 330.40 & 373.50 \\
\hline $\mathrm{L}_{2}=15 \mathrm{~kg} \mathrm{ha}^{-1}$ & 69.86 & 10.82 & 6.31 & 5.82 & 0.23 & 1.89 & 80.89 & 370.58 & 415.48 \\
\hline $\mathrm{L}_{3}=30 \mathrm{~kg} \mathrm{ha}^{-1}$ & 73.45 & 11.86 & 6.54 & 6.12 & 0.22 & 1.74 & 85.68 & 402.14 & 438.56 \\
\hline $\mathrm{L}_{4}=45 \mathrm{~kg} \mathrm{ha}^{-1}$ & 76.40 & 12.88 & 6.84 & 6.55 & 0.18 & 1.54 & 93.43 & 452.51 & 483.03 \\
\hline C.D & 2.47 & 1.07 & 0.23 & 0.23 & 0.03 & 0.23 & 2.92 & 13.45 & 15.88 \\
\hline \multicolumn{10}{|l|}{ SxL } \\
\hline $\mathbf{S}_{1} \mathbf{L}_{1}$ & 64.53 & 10.41 & 5.99 & 5.50 & 0.27 & 2.12 & 75.97 & 339.48 & 377.11 \\
\hline $\mathbf{S}_{1} \mathbf{L}_{2}$ & 70.41 & 11.13 & 6.50 & 6.12 & 0.23 & 0.23 & 83.84 & 388.11 & 423.74 \\
\hline $\mathbf{S}_{1} \mathbf{L}_{3}$ & 76.00 & 12.94 & 6.62 & 6.20 & 0.20 & 0.20 & 88.49 & 419.70 & 447.60 \\
\hline $\mathbf{S}_{1} \mathbf{L}_{4}$ & 79.36 & 13.94 & 6.98 & 6.70 & 0.17 & 0.17 & 96.73 & 475.61 & 497.18 \\
\hline $\mathbf{S}_{2} \mathbf{L}_{1}$ & 63.36 & 9.77 & 5.67 & 5.23 & 0.28 & 0.28 & 73.00 & 321.32 & 369.89 \\
\hline $\mathbf{S}_{2} \mathbf{L}_{2}$ & 69.31 & 10.50 & 6.13 & 5.52 & 0.24 & 0.24 & 77.93 & 353.05 & 407.21 \\
\hline $\mathbf{S}_{2} \mathbf{L}_{3}$ & 70.90 & 10.78 & 6.45 & 6.05 & 0.23 & 0.23 & 82.88 & 384.58 & 429.52 \\
\hline $\mathbf{S}_{2} \mathbf{L}_{4}$ & 73.44 & 11.81 & 6.69 & 6.39 & 0.19 & 0.19 & 90.13 & 429.41 & 468.87 \\
\hline C.D @5\% & NS & NS & NS & NS & NS & NS & NS & NS & NS \\
\hline CV & 2.82 & 7.59 & 2.90 & 3.14 & 11.04 & 10.11 & 2.82 & 2.79 & 3.00 \\
\hline
\end{tabular}


Table.3 Effect of various levels of sulphur on storage loss and bulb quality of onion

\begin{tabular}{|c|c|c|c|c|c|c|}
\hline Treatments & PLW (\%) & Sprouting (\%) & Rotting (\%) & $\begin{array}{c}\text { Total } \\
\text { Losses } \\
(\%)\end{array}$ & $\begin{array}{l}\text { T.SS } \\
(\%)\end{array}$ & $\begin{array}{l}\text { Pyruvic acid } \\
\left(\boldsymbol{\mu} \mathrm{mol} \mathrm{g}^{-1}\right)\end{array}$ \\
\hline \multicolumn{7}{|l|}{ Sources } \\
\hline $\mathbf{S}_{1}$ & 17.79 & 9.73 & 3.44 & 30.96 & 11.01 & 6.78 \\
\hline $\mathbf{S}_{2}$ & 19.67 & 10.70 & 3.78 & 34.15 & 10.51 & 6.54 \\
\hline C.D & 0.90 & 0.99 & 0.28 & - & 0.36 & 0.22 \\
\hline Levels & & & & 39.96 & & \\
\hline$L_{1}=0 \mathrm{~kg} \mathrm{ha}^{-1}$ & 22.54 & 12.88 & 4.54 & 31.83 & 10.06 & 6.34 \\
\hline $\mathrm{L}_{2}=15 \mathrm{~kg} \mathrm{ha}^{-1}$ & 19.58 & 10.97 & 3.76 & 24.61 & 10.56 & 6.59 \\
\hline $\mathrm{L}_{3}=30 \mathrm{~kg} \mathrm{ha}^{-1}$ & 17.30 & 9.21 & 2.87 & 29.21 & 10.88 & 6.65 \\
\hline $\mathrm{L}_{4}=45 \mathrm{~kg} \mathrm{ha}^{-1}$ & 15.50 & 7.81 & 78.65 & 32.54 & 11.54 & 7.06 \\
\hline C.D & 0.90 & 0.99 & 0.40 & 0.94 & 0.52 & 0.32 \\
\hline \multicolumn{7}{|l|}{ SXL } \\
\hline $\mathbf{S}_{1} \mathbf{L}_{1}$ & 22.50 & 12.40 & 4.56 & 39.46 & 10.15 & 6.35 \\
\hline $\mathbf{S}_{1} \mathbf{L}_{2}$ & 17.83 & 10.57 & 3.43 & 31.83 & 10.83 & 6.68 \\
\hline $\mathbf{S}_{1} \mathbf{L}_{3}$ & 16.04 & 8.71 & 3.16 & 27.91 & 11.17 & 6.75 \\
\hline $\mathbf{S}_{1} \mathbf{L}_{4}$ & 14.77 & 7.23 & 2.61 & 24.61 & 11.90 & 7.35 \\
\hline $\mathbf{S}_{2} \mathbf{L}_{1}$ & 22.57 & 13.36 & 4.52 & 40.45 & 9.98 & 6.33 \\
\hline $\mathbf{S}_{2} \mathbf{L}_{2}$ & 21.32 & 11.37 & 4.08 & 36.77 & 10.29 & 6.51 \\
\hline $\mathbf{S}_{2} \mathbf{L}_{3}$ & 18.56 & 9.70 & 3.39 & 31.65 & 10.58 & 6.56 \\
\hline $\mathbf{S}_{2} \mathbf{L}_{4}$ & 16.23 & 838 & 3.12 & 27.55 & 11.18 & 6.77 \\
\hline C.D (5\%) & 1.27 & NS\ & NS & --- & NS & NS \\
\hline C.V & 3.88 & 7.80 & 8.94 & --- & 3.87 & 3.82 \\
\hline
\end{tabular}


Table.4 Effect of various levels of sulphur on nutrient uptake of onion (Allium Cepa L.)

\begin{tabular}{|c|c|c|c|c|}
\hline Treatment & $\begin{array}{l}\text { Nitrogen Uptake } \\
\quad\left(\mathrm{Kg} \mathrm{ha}^{-1}\right)\end{array}$ & $\begin{array}{l}\text { Phosphorus Uptake } \\
\left(\mathrm{Kg} \mathrm{ha}^{-1}\right)\end{array}$ & $\begin{array}{l}\text { Potassium Uptake } \\
\left(\mathrm{Kg} \mathrm{ha}^{-1}\right)\end{array}$ & $\begin{array}{l}\text { Sulphur Uptake } \\
\quad\left(\mathrm{kg} \mathrm{ha}^{-1}\right)\end{array}$ \\
\hline \multicolumn{5}{|l|}{ Sources } \\
\hline $\mathbf{S}_{1}$ & 85.25 & 20.51 & 70.82 & 27.93 \\
\hline $\mathbf{S}_{2}$ & 81.71 & 18.74 & 68.18 & 25.63 \\
\hline C.D & 2.68 & 0.57 & 1.78 & 0.66 \\
\hline \multicolumn{5}{|l|}{ Levels } \\
\hline$L_{1}=0 \mathrm{~kg} \mathrm{ha}^{-1}$ & 71.85 & 14.88 & 60.75 & 20.77 \\
\hline$L_{2}=15 \mathrm{~kg} \mathrm{ha}^{-1}$ & 81.25 & 18.15 & 67.24 & 24.61 \\
\hline$L_{3}=30 \mathrm{~kg} \mathrm{ha}^{-1}$ & 86.39 & 21.57 & 71.37 & 29.21 \\
\hline $\mathrm{L}_{4}=45 \mathrm{~kg} \mathrm{ha}^{-1}$ & 94.44 & 23.89 & 78.65 & 32.54 \\
\hline C.D & 3.78 & 0.81 & 2.52 & 0.94 \\
\hline \multicolumn{5}{|l|}{ SXL } \\
\hline $\mathbf{S}_{1} \mathbf{L}_{1}$ & 73.71 & 15.25 & 61.03 & 21.39 \\
\hline $\mathbf{S}_{1} \mathbf{L}_{2}$ & 82.43 & 19.25 & 68.87 & 25.42 \\
\hline $\mathbf{S}_{1} \mathbf{L}_{3}$ & 87.97 & 22.45 & 72.76 & 30.76 \\
\hline $\mathbf{S}_{1} \mathbf{L}_{4}$ & 96.91 & 25.08 & 80.61 & 34.17 \\
\hline $\mathbf{S}_{2} \mathbf{L}_{1}$ & 69.99 & 14.51 & 60.46 & 20.15 \\
\hline $\mathbf{S}_{2} \mathbf{L}_{2}$ & 80.08 & 17.05 & 65.60 & 23.81 \\
\hline $\mathbf{S}_{2} \mathbf{L}_{3}$ & 84.81 & 20.69 & 69.97 & 27.65 \\
\hline $\mathbf{S}_{2} \mathbf{L}_{4}$ & 91.96 & 22.71 & 76.70 & 30.92 \\
\hline C.D (5\%) & NS & NS & NS & NS \\
\hline C.V & 3.66 & 3.34 & 2.93 & 2.83 \\
\hline
\end{tabular}


The increase in growth, yield and yield related attributes could be due to its role in balanced nutrition and performs in any physiological functions like synthesis of sulphur containing aminoacids, development of profused root system, resulting in increased nutrient uptake, ultimately increasing the photosynthesis, leading to improved growth, higher yield. Similar findings have also been reported by better quality, higher nutrient uptake and sustainable nutrient bulb up in the soil (Dudhat et al., 2011, Yaduvanshi and Yadav 2007, Jaggi, 2004, Tripathy et al., 2013, Magray et al., 2017, Nasrin et al., 2007.

In conclusion, the results can be summarised as, the application of sulphur @ $45 \mathrm{~kg} \mathrm{ha}^{-1}$ through gypsum is useful to promote better growth, yield, quality, storage life of onion and sustainable nutrient build up in the soil.

\section{References}

Ahmed M.K, DK Aditya, Siddigue M.A 1999. Effects of nitrogen and sulphur application on the growth and yield of onion cv. Faridpur Bhatti, Bangledesh Hort, 1988; 46(1): 36-41.

Alam M.D, Effect of Paclobutrozol and S fertiliser on the growth, yield and sulphur content of garlic. MSc. Thesis, Bangladesh Agri, Univ, Mymensingh, 1995: 92-95.

Alam M.D, Rahim, M.A, Sultana, MS. Effect of paclobutrazol and sulphur fertiliser on the growth and yield of garlic. Bangladesh Journal of Training and Development, 1999; 12(1-2):223-230.

Annonymous, 2016-17. National Horticulture Board, Area and Production of Vegetables for the year 2013-14.

Anwar, M.N., Sarker, J.U., Rahman, M., Islam, M.A., Begum, M., 2001. Response of onion to nitrogen, phosphorus, potassium, sulphur and zinc. Bangladesh Journal of Environment Science 7, 68-72
August KT. Hyposholesterolacmic effect of garlic (Allium Sativum L.). Indian J Expt. Biol, 1977: 15(6):489-490.

Aulakh MS. Crop response to sulphur nutrition in Y.P. Abrol and A. Ahmad (eds). Sulphur in plant. Kluwer Academic Publ. Dordrecht, 2003; 341-354. Aus J. Food Ag-Ind. Special Issue, 2009; 18-23.

Bose TK, MG Som, Vegetable Crops in India 1990: 583-601.

Channagouda, R.F., Ajjappalavara, P., Kamble, A.S., 2009. Response of onion to different levels of irrigation and sulphur in alfisoils of Northern transitional tract of Karnataka. The Asian Journal of Horticulture 4(1), 152-155

Chesnin, L. and Yien, C.H. 1951. Turbidimetric determination of available sulphate. Soil Science Society of America Proceedings 15: 149-151.

Dudhat M S, Chovatia P K, Sheta B T and Thesiya N M 2011 Effect of sources and levels of sulphur fertilizers on bulb yield of onion (Allium cepa L.). Intl. J. Pl. Sci. 6: 134-136.

Farooqui MA, Naruka IS, Rathore SS, Singh PP, Shaktawat RPS et al., Effect of nitrogen and sulphur levels on growth and yield of garlic (Allium sativum L.). FAOSTAT 2011 Food and Agriculture

Hore JK. Ghanti S, Chanchan M. Influence of nitrogen and sulphur nutrition on growth and yield of garlic (Allium sativum L.). Journal of Crop and Weed. 2014; 10(2): 14-18

Hossain MM. Effect of different levels of nitrogen and potash on the growth and yield of garlic.MS Thesis. Dept. Hort Bangladesh Agril. Univ, Mymensingh, 1997; 65.

Jackson, M.L. 1967. Soil chemical analysis. Prentice Hall of India Pvt. Ltd., New Delhi, pp. 162-165.

Jackson, M.L. 1973. Soil chemical analysis. Prentice Hall of India Pvt. Ltd., New Delhi. 
Jaggi R.C. Effect of sulphur levels and sources on composition and yield of onion (Allium cepa). Ind J of Agri. Sci., 2004; 74(4); 219-220.

Jaggi RC, Dixit SP, Onion (Allium cepa L.) response of sulphur in representative vegetable growing soils of Kangra Valley of Himachal Pradesh. Ind. J. Agri. Sci., 1999; 69(4):289-291.

Kumar, A., Singh, O., 1994. Role of sulphur in nutrient utilization and catalase activity in onion crop. Indian Journal Agricultural Research, 28, 15-19.

Magray M. Mudasir, Chattoo. M.A, Narayan. S, Najar, G.R, Jabeen Nayeema and Ahmad Tariq. Effect of sulphur and potassium applications on growth and chemical characteristics of garlic 2017. The Bioscan, 12(1):471-475.

Nagaich KN, Trivedi SK, Lekhi R. Effect of sulphur and potassium fertilisation in onionj (Allium cepa L). Hort. J., 1999; 12:25-31.

Nasreen S, Haque M, Hossain M, Farid A (2007) Nutrient uptake and yield of onion as influenced by nitrogen and sulphur fertilization. Bangladesh J Agric Res 32: 413-420.

Olsen, S.R., Coleman, C.W., Watnabe, F.S. and Dean, L.A. 1954. Estimation of available phosphorus with sodium bicarbonate. United States Department of Agriculture Circular 939: 19.

Panse VG, Sukhatme PU, Statistical Methods for Agricultural workers, ICAR, New Delhi, 1978.

Pitam D. Medina Research Station and John Burt, Horticulture Adviser, South Perth, 2008.
Randle. WM. Onion germplasm interacts with sulphur fertility for plant utilisation and bulb pungency. Euphytica.1992; 59(23):151-6.

Subbiah, S.S. and Asija, C.L. 1956. A rapid procedure for the estimation of available nitrogen in soil. Current Science, 25: 259-260.

Tandon, H.L.S. 1993. Methods of analysis of soils, plants, waters and fertilizers. Fertilizer development and consultant organization, New Delhi.

Thippeswamy, H.J., 1993. Leaf sampling guide and nutrient norms in yield and quality in relation to applied sulphur to onion. M.Sc. (Agri.) Thesis, University of Agricultural Science, Bangalore

Tripathy, P., Sahoo, B.B., Priyadarshini, A., Das, S.K. and Dash, D.K. 2013. Effect of sources and levels of sulphur on growth, yield and bulb quality in onion (Allium сера L.). International Journal of Bioresources and Stress Management 4(4):641-644.

Walkley, A. and Black, J.A. 1934. An estimation of the method for determining soil organic carbon and a proposed modification of the chemical and titration method. Soil Science, 37: 29-39.

Williams, C.H. and Steinberg, A. 1959. Soil sulphur fractions and chemical indices of available sulphur in some Australian soils. Australian Journal of Agricultural Research 10: 340-352.

Yaduvanshi N P S and Yadav D V 2007 Soil sulphur status and sugarcane response to different levels, methods and source of sulphur application. Curr. Agri. 31: 5559.

\section{How to cite this article:}

Chattoo, M.A., M. Mudasir Magray, Ajaz Ah Malik, M.D. Shah and Chisti, J.A. 2019. Effect of Sources and Levels of Sulphur on Growth, Yield and Quality of Onion (Allium cepa L.). Int.J.Curr.Microbiol.App.Sci. 8(03): 1462-1470. doi: https://doi.org/10.20546/ijcmas.2019.803.170 